\title{
The Correlation Between Community Health Cadres Knowledge and the Role in Preventing COVID-19 in Teluk Village
}

\author{
Salsabila Thalita Dama Agatha ${ }^{1}$, Diyah Yulistika Handayani ${ }^{2}$ \\ ${ }^{1}$ Student of Nursing Department, Faculty of Health Sciences, Universitas Muhammadiyah Purwokerto \\ ${ }^{2}$ Lecturer of Nursing Department, Faculty of Health Sciences, Universitas Muhammadiyah Purwokerto
}

\section{ARTICLE INFO}

Article history:

DOI:

$\underline{10.30595 / \mathrm{pshms.v2i.229}}$

Submitted:

December 6, 2021

Accepted:

January 21, 2022

Published:

January 26, 2022

Keywords:

CHCs; COVID-19; Knowledge;

The Role in preventing COVID-19

\begin{abstract}
Background : According to data from Banyumas Health Agency(2021), Teluk Village was once a red zone because there were 14 confirmed cases of COVID-19. Therefore, several activities involving the community, including Integrated Health Services Post, were suspended. During the pandemic, the majority of mothers are worried to take their children to health facilities to be immunized, whereas immunization is very important. In order to reduce parents' worries, the role of Community Health Cadres(CHCs) is needed in providing information related to safe immunization procedures.

Objective : The purpose of this study was to figure out the correlation between CHCs knowledge and the role in preventing COVID-19. This was quantitative research with a cross-sectional approach.

Method : This research has been carried out on 64 CHCs in Teluk Village. Percentages and chi-square test analysis were employed to answer the research problems.

Results : The results indicated that most of the respondents graduated from high school and were of productive age. In addition, most of them have become CHCs for 15 years. $46.9 \%$ of the respondents had a good level of knowledge about COVID-19, while 53.1\% had a moderate level. The role of most of the cadres in preventing COVID-19 was in the optimal category $(60.9 \%)$, while the rest $(39.1 \%)$ was not optimal.

Conclusion : The p-value was 0.001(0.05) therefore it can be concluded that there is a correlation between cadres' knowledge about COVID-19 and the roles in preventing the disease.
\end{abstract}

This work is licensed under a Creative Commons Attribution 4.0 International License.

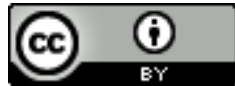

Corresponding Author:

Salsabila Thalita Dama Agatha,

Student of Nursing Department, Faculty of Health Sciences, Universitas Muhammadiyah Purwokerto

Email: salsabilathalita31@gmail.com

\section{INTRODUCTION}

The Coronavirus Disease 2019 (COVID-19), often known as SARS-CoV 2, is a respiratory tract infection that was first reported in December 2019. (severe acute respiratory syndrome coronavirus 2). COVID-19 was first detected in Wuhan, China (World Health Organization, 2020a). WHO (World Health Organization) declared COVID-19 as a pandemic on March 11, 2020, due to the alarming rate of spread throughout the world.[1]

Based on data from the World Health Organization (WHO) as of August 4, 2021, COVID-19 cases have infected 223 countries, including Indonesia, with a total of 199,466,211 confirmed cases globally (World Health Organization, 2020b). The number of cases in Indonesia was growing day by day. On August 4, 2021, the total number of cases had reached 3,532,567, including 100,636 deaths (BNPB, 2020). COVID19 cases in Central Java reached 397,839 cases until August 4, 2021 (Central Java Health Office, 2021), while positive confirmed COVID-19 cases in Banyumas reached 32,766 cases until August 4, 2021 (Banyumas Health Office, 2021), with a distribution map in Teluk Purwokerto Selatan Village showing 435 people were declared cured, 18 people were still in hospital, and 36 people did self-isolation.[2] 
The government has developed a policy to restrict the spread of COVID-19 by enacting Large-Scale Social Restrictions (PSBB), in accordance with Government Regulation No. 21 of 2020.[3] The Minister of Health authorized the policy, which went into action on April 7, 2020.[4] This policy, which was implemented to restrict community movement, had gone through numerous names and formats, including PSBB, Transitional PSBB, Strict PSBB, Transitional PSBB 2, Java-Bali PPKM, Micro PPKM, Emergency PPKM, and level 3 and 4 PPKM. Vaccination is also part of a new approach to prevent COVID-19.

The implementation of the policy has an effect on a number of regions' readiness to prepare for it, including the Banyumas Regency Government. According to the table for COVID-19 distribution in Central Java Banyumas, which is ranked 2 out of 35 regencies in Central Java, has a relatively high number of COVID-19 cases.[5] The Banyumas Regency Government has implemented several policies, including providing quarantine places in every village to prepare for the possibility of home comers from the capital city, closing roads or imposing a curfew from 8 PM to 6 AM, wearing masks when traveling, maintaining distance, temporarily eliminating social activities that cause crowds, and providing quarantine places at GOR (Sport Centre) Satria. [6] Banyumas had currently implemented PPKM level 4, which had been extended from August 10 to August 16, 2021, and involved the closure of multiple highways. This was done in order to prevent COVID-19 from spreading in Banyumas.

The government, through this policy, urged the people to follow and obey the restrictions that have been established in order to break the COVID-19 transmission chain. According to the results of my interview with one of the officers of the COVID-19 Task Force, the current phenomenon in the field was that many people still did not care about the government's regulations and policies. Wearing masks, breaking curfews, and crowding are just a few examples.

The COVID-19 pandemic is a particularly troubling time for women with toddlers. In the meantime, immunization is essential for toddlers in order to protect them from a variety of diseases. According to the results of my interviews with numerous cadres, the Posyandu (Integrated Healthcare Center) has been temporarily suspended since March 2020. The Posyandu, however, had been functioning again since September 2020, by tightening health protocols. Due to an increase of COVID-19 cases, the Posyandu was once again halted from November 2020 to August 2021. The threat to children's health is one of the issues that has gotten a lot of attention during the pandemic. Because Posyandu and Puskesmas (Health Center) have closed their immunization clinics for toddlers, this is the case. During a pandemic, most mothers are concerned about taking their children to health facilities to be immunized, despite the fact that immunization is essential. children to health facilities to be immunized, despite the fact that immunization is essential. So, it is likely that basic immunization coverage for children will decrease.

The South Purwokerto area, particularly Teluk Village, was originally considered a red zone due to 14 COVID-19 positive cases that have now been declared cured. However, this is likely to heighten parental anxiety when it comes to taking their children to the doctor for immunizations. Cadres must play an important role in delivering important information about safe and comfortable immunization processes during the pandemic to alleviate parental anxieties. Cadres in the village play an important role in community empowerment since they will have more personal interaction with the community, which will be especially important during a pandemic. Posyandu cadres will continue to deliver services and counseling as community learning facilitators. Posyandu cadres can be seen as facilitators who help people get better by mentoring, supervising, and guiding them. Therefore, researchers are interested in doing study on "The Correlation of between Cadre Knowledge of COVID-19 and the Role in Preventing COVID-19 in Teluk Village" in addition to learning more about the correlation between the knowledge of cadres about COVID 19 and their preventive roles during COVID-19 pandemic.

\section{RESEARCH METHOD}

This research took a cross-sectional approach and employed a quantitative method. Teluk Village was the location of this study. The research took place in April and May 2021. This research included a sample of 64 people from 135 populations.

The research applied the percentage and chi square test analysis to respond to the problem formulation. Respondents were given a questionnaire with 30 questions that included demographic information (level of education, age, and duration as a cadre) as well as question indicators such as the definition of COVID-19, length of exposure, symptoms, impact, transmission, prevention, and perceptions of COVID-19 vaccination. The measurement of knowledge scores is divided into three levels, as follows: a). If the score is between 76 and $100 \%$, this is a good category; b). If the score is between 56 and $75 \%$, this is the fair category; c). If the value is less than $56 \%$, it falls into the poor category.

Meanwhile, the COVID-19 prevention role score is divided into two categories, as shown below: a). If the value is $>50 \%$, the role is optimal; b). If the value is $<50 \%$, the role is not optimal. 


\section{RESULT AND DISCUSSIONS}

\subsection{Result}

Table 1. Characteristics of Respondents

\begin{tabular}{lll}
\hline Characteristics & Frequency $(\mathrm{N})$ & Percentage $(\%$ \\
\hline Education Level & & \\
Elementary & 4 & 6,3 \\
SLTP (Junior High) & 9 & 14,1 \\
SLTA (Senior High) & 41 & 64,1 \\
Diploma & 5 & 7,8 \\
Bachelor & 5 & 7,8 \\
\hline Age (years) & & \\
$<40$ & 14 & 21,9 \\
$40-50$ & 25 & 39,1 \\
$50-60$ & 22 & 34,4 \\
$>60$ & 3 & 4,7 \\
\hline Length of time as a cadre (years) & \\
$1-10$ years & 37 & 57,8 \\
$11-20$ years & 22 & 34,4 \\
$>20$ years & 5 & 7,8 \\
\hline Total & 64 & 100 \\
\hline
\end{tabular}

There were 4 people with an elementary education level (6.3\%), 9 people with a junior high school education $(14.1 \%), 41$ people with senior high school education $(64.1 \%), 5$ people with a diploma $(7.8 \%)$, and 5 with bachelor degree $(7.8 \%)$ among the 64 respondents. In this study, there were 14 persons under the age of $40(21.9 \%), 25$ people between the ages of 40 and $50(39.1 \%), 22$ people between the ages of 50 and $60(34.4 \%)$, and 3 people beyond the age of $60(4.7 \%)$. The length of time each cadre has been a cadre varies, with 37 people $(57.8 \%)$ having been cadres for $1-10$ years, 22 people $(34.4 \%)$ for $11-20$ years, and 5 people $(7.8 \%)$ having been cadres for more than 20 years. (Table 1$)$.

Table 2. Distribution of Cadre Knowledge Categories about COVID-19

\begin{tabular}{lll}
\hline Categories & Frequency $(\mathrm{N})$ & Percentage $(\%)$ \\
\hline Good & 30 & 46.9 \\
Fair & 34 & 53.1 \\
\hline Total & 64 & 100 \\
\hline
\end{tabular}

From 64 respondents, 30 people $(46.9 \%)$ had good knowledge $(46.9 \%)$, while 34 people $(53.1 \%)$ had moderate or fair knowledge (Table 2).

Table 3. Distribution of COVID-19 Prevention Role

\begin{tabular}{lll}
\hline Categories & Frequency $(\mathrm{N})$ & Percentage $(\%)$ \\
\hline Optimal & 39 & 60.9 \\
Not Optimal & 25 & 39.1 \\
\hline Total & 64 & 100 \\
\hline
\end{tabular}

From 64 respondents, 39 people $(60.9 \%)$ played an optimal role, while 25 people played a nonoptimal role $(39.1 \%)$ in preventing COVID-19 (Table 3).

Table 4. Correlation between Cadre Knowledge about COVID-19 and the Role of COVID-19 Prevention

\begin{tabular}{|c|c|c|c|c|c|c|c|c|}
\hline \multirow{3}{*}{ Knowledge } & \multicolumn{4}{|c|}{ Roles of Covid-19 Prevention } & \multirow{2}{*}{\multicolumn{2}{|c|}{ Total }} & \multirow{3}{*}{$\begin{array}{l}\text { OR } \\
(95 \% \mathrm{CI})\end{array}$} & \\
\hline & \multicolumn{2}{|c|}{ Optimal } & \multicolumn{2}{|c|}{ Not Optimal } & & & & \\
\hline & $\mathrm{N}$ & $\%$ & $\mathrm{~N}$ & $\%$ & $\mathrm{~N}$ & $\%$ & & \\
\hline Good & 12 & 40 & 18 & 60 & 30 & 100 & 0,173 & \\
\hline Moderate & 27 & 79,4 & 7 & 20,6 & 34 & 100 & $0,05-0,52$ & $=0,001$ \\
\hline Total & 39 & 60,9 & 25 & 39,1 & 64 & 100 & & \\
\hline
\end{tabular}

The Asymp value is shown in table 4. Sig. (2-sided) $0.001<0.05$, indicating that $\mathrm{H} \alpha$ was accepted. The Asymp value showed. Sig. (2-sided) $<0.05$, indicating that there is a correlation between cadre 
knowledge of COVID-19 and the role of COVID-19 prevention in Teluk Village. The OR value obtained from the analysis is 0.173 , indicating that cadres with good knowledge are at risk of performing the COVID19 preventive role 0.173 times more often than cadres with fair knowledge, with a $95 \%$ confidence level of 0.05 (the lowest risk) and 0.52 (the highest risk). (Table 4).

\subsection{Discussion}

\subsubsection{Characteristics of Respondents}

\section{a) Education Level}

According to the findings of the study, the majority of cadres, $64.1 \%$, (41 respondents), graduated from high school education level. According to Putri (2017), education is one of the elements that influences a person's level of knowledge; the greater a person's education, the more information they possess. Cadres' level of education will have an impact on how they view their roles and responsibilities. According to research using a questionnaire, the Chinese population, which is largely female and well educated, has a good level of knowledge (90\%) on the COVID-19 knowledge.[7]

According to my research, a person's knowledge is influenced by more than just their educational degree. [8] If basic education or higher education included five basic modules on Posyandu management, cadres' knowledge and skills would improve.[9] Formal education, participation in Posyandu, and length of service as a cadre can all influence cadres' level of knowledge in carrying out their roles. Good knowledge of health cadres, is very significant and useful for the execution of health programs. It will enable health cadres to comprehend the occurrence and tackle any problem in improving health in its place with good understanding.[10]

\section{b) Age}

According to the findings of this study, almost all cadres were between the ages of 40 and 50, with $39.1 \%$ (25 respondents). Cadres' ages ranged from 30 to 60 years old, with developmental duties such as developing activities to fill spare time, as well as changes in interest in civic and social responsibilities and a focus on family activities.[11] According to the Indonesian Ministry of Health, the productive age ranges from 15 to 64 years. This means that participants in this study were of productive age.

There is a significant relationship between age and the level of knowledge of posyandu cadres ( $\mathrm{p}<$ $0.05)$, in the low category $(r=0.241)$ and one way (positive $r$ value).[7] It means that the older the age Posyandu cadres, the better the level of knowledge. One of the factors that influence knowledge is age. The older they get, the more their grasping power and mindset will develop so that the knowledge they gain is getting better. The research also shows that there is no significant relationship between age and skill level of Posyandu cadres $(p>0.05)$. However, based on the value of the correlation coefficient $(r)$, it is one-way (positive $r$ value), implying that the higher the skill level of the Posyandu cadres, the older they are. This can demonstrate that as a person grows older, his or her level of maturity and strength in thinking and working will increase, but there are physical factors that can obstruct the learning process in adults, resulting in a reduction in thinking and working ability.

Theoretically in productive age have good activity because they are physically stronger, active, flexible, creative, and nimble. Meanwhile, cadres in the unproductive age group have frequently suffered from physical degeneration, but they have a strong work ethic and a strong feeling of responsibility for their work.[12]

\section{c) Length of Being a Cadre}

The majority of cadres, 37 respondents $(57.8 \%)$, have been in their positions for one to ten years, according to the findings of this study. In addition, 22 respondents had served 11 to 20 years as cadres. Cadres in charge for longer than three years are more motivated to participate actively in Posyandu than cadres in charge for less than three years. The length of time spent at work is related to the amount of experience. A person's workplace environment activity is influenced by personal previous experiences.[13]

Significant correlation between length of time as a cadre and Posyandu cadres' level of knowledge ( $p$ 0.05), in the high category $(r=0.776)$ and one-way (positive $r$ value), meaning that the longer the posyandu cadre is, the better the level of knowledge. Furthermore, the results of this study revealed a strong one-way correlation ( $\mathrm{p}$ 0.05) between the amount of time spent as a cadre and the skill level of Posyandu cadres in the low category $(r=0.317)$, meaning that the more time Posyandu cadres spend on the service, the better their skills develop.[14]

According to Lawrence Green's theory, the characteristics that impact behavior are predisposing factors, one of which is the length of time as a posyandu cadre. It is intended that the longer they work as 
posyandu cadres, the more experience and knowledge they would gain, allowing them to better assist the people that visit the Posyandu.

\subsubsection{Knowledge of Cadre}

According to the findings of this study, 30 cadres (46.9\%) in Teluk Village, Puskesmas Purwokerto Selatan, had high knowledge and 34 cadres (53.1\%) had fair knowledge of the Puskesmas Purwokerto Selatan. This demonstrates that there was not much of a difference between cadres with moderate and good knowledge..

Knowledge has an impact on a person's education and behavior. The more educated a person is, the easier it is for him or her to receive knowledge. This is supported by the research data, which shows that the majority of cadres in this study had a high school education level of 41 cadres $(64.1 \%)$. Teluk Village cadres have a high school education on average, so they can obtain information not only through formal education but also through non-formal education, which might have an impact on short-term knowledge. This may change their level of knowledge. Various sources of information, such as social media, television, and radio, can shape public opinion and trust by influencing public knowledge.

According to the findings of a study conducted [15], nurses in Iran obtain information about COVID-19 from various media such as websites, Whatsapp, and television, and half of Iranian nurses $(56.5 \%)$ have a comprehensive knowledge of the spread of this disease. According to Rinayati,[10] good knowledge of health cadres is important and beneficial for the implementation of health programs in Gondoriyo Village because it allows health cadres to understand phenomena and to solve problems in improving health in their community.

It is in line with Profita's research which shows that cadres who have a good level of knowledge regarding matters related to Posyandu. The percentage of active cadres is 22 cadres $(84.6 \%)$, compared to the percentage of cadres with fair knowledge of 10 cadres (52). ,6\%). Cadres with less knowledge represents the lowest percentage of active cadres, namely 4 cadres (26.7\%).[16]

Based on table 4.2, the knowledge of cadres about COVID-19 is good, especially on questions about time of exposure, symptoms, prevention, and vaccination, while respondents' answers are still lacking on questions about people infected with COVID-19, exposure to the elderly and comorbidities, transmission, and vaccinating pregnant or lactating women.

\subsubsection{The Roles in Preventing COVID 19}

Based on the results of research that has been carried out, it shows that the majority of cadres have an optimal role in preventing COVID-19 with 60.9\% (39 respondents). During the pandemic, villages formed a COVID-19 Task Force consisting of village heads and village officials, RW heads, RT heads, satlinmas (Community Protection Unit), babinsa (Village Advisory Officer), bhabinkamtibmas (Community Police Officers), health workers, cadres, PKK (Family Welfare Program), and youth organizations. Cadres are asked to work closely with village midwives in the health sector to prevent and control COVID-19. Although becoming a cadre is a purely voluntary activity, Teluk Village cadres take each activity very seriously. This is supported by research findings that reveal there are more cadres with optimal roles than non-optimal positions. According to the responses to the questionnaire, 13 cadres indicated they never monitored or limited citizen mobility during the pandemic, while 20 said they always gave socialization about the significance of wearing masks. Wahyutomo found that a cadre plays a significant role in implementing posyandu activities and mobilizing community activities in his research.[17]

According to research conducted by Retnaningtyas, cadres are people who are close to the community and have been prepared with health knowledge, and their role in efforts to promote health is at the forefront.Cadres are also required to be able to tackle common community problems that require immediate attention. Cadres do not function in a closed system; however, they work in the health system as activists. Therefore, health workers, as skilled and experienced mentors, must foster, train, guide, and support cadres.[18]

One of the roles of the community in improving welfare in their local region is the role of a cadre in every activity. Cadres are responsible for every activity they carry out, therefore if one fails to carry out his/her responsibilities to the best of his/her ability, the activity will not go smoothly and will have an impact on the community. This will have a direct effect on the success of the program run by the cadres.

\subsubsection{The Correlation between Cadre Knowledge about COVID-19 and the Roles in Preventing COVID-19 in Teluk Village}

According to the findings of the study, the $\mathrm{p}$ value for the correlation between cadre knowledge and the role of COVID-19 prevention is 0.001, implying that there is a correlation between the two.. Cadres' level of knowledge will have an impact on how they carry out their roles. According to Permenkes No. 3 of 2015, 
cadres play a role in growing and developing, as well as organizing initiatives, participation, and self-help mutual assistance This is what motivates a cadre to carry out tasks with a high level of knowledge. Cadres' ability to carry out their tasks as cadres will be enhanced by a high level of knowledge.

Because of the rising number of COVID-19 cases during this pandemic, posyandu operations were halted. Meanwhile, immunization of toddlers is crucial to avoid them from suffering harmful infections. As a result, cadres are required to provide information to mothers on the protocol for administering immunizations during the pandemic. Cadres are at the forefront of community mobilization for COVID-19 prevention and management. In the health sector, village midwives and posyandu cadres play a key role in implementing the "Jogo Tonggo" Force or a program of neighbor health care movement.

Based on the respondents' answers to the questionnaire, it shows that the knowledge of cadres about COVID-19 is good, but the vaccination questionnaire is still lacking, especially on vaccination targets. In the COVID-19 prevention role questionnaire, there were 13 cadres who had never monitored or limited the mobility of citizens, 10 cadres had never provided information regarding health protocols during the pandemic, and 9 cadres had never provided socialization regarding vaccination. A total of 29 cadres said that they sometimes educate the public to stay calm and not panic during the pandemic and 27 cadres urge the public on the importance of immunization during the pandemic. The cadres also said that they often provide socialization about COVID-19 to the community and always provide socialization about the importance of using masks, washing hands in 6 steps, and urging people to implement PHBS..

According to the risk estimate table, cadres with good knowledge have a 0.50 times better chance of playing an optimal COVID-19 prevention role compared to cadres with moderate knowledge, and cadres with fair knowledge have a 2.91 times better chance of playing a non-optimal COVID-19 prevention role compared to knowledgeable cadres.

The findings of this study are in line with those of Pakasi [19] which found that there is a correlation between health cadre knowledge and posyandu service in the working area of the Kakaskasen Health Center, North Tomohon District, Tomohon City. According to Andira et al. (2013), people with a high level of knowledge will do well, whereas those with a low level of knowledge will perform poorly. This illustrates how a person's level of knowledge influences how a cadres perform their duties.

Knowledge is a crucial domain in shaping one's behaviors. Ones made with sufficient knowledge will last longer than actions taken without it. Cadres with a high level of knowledge will exhibit good behavior when acting as a cadre. Increasing or decreasing one's knowledge can have an impact on one's comprehending, thinking, and analyzing abilities. This might cause a person's behavior to shift as a result of a changed impression of the thing being observed.

\section{CONCLUSION}

After conducting research on the correlation between cadre knowledge about COVID-19 and the role of preventing COVID-19 in Teluk Village, it could be concluded that: 1). Most of the respondents in this study were mostly high school graduates and in productive age.The majority of the respondents in this study had been cadres for between one and ten years; 2). there were $46.9 \%$ (30 respondents) with a high level of knowledge, $53.1 \%$ (34 respondents) with a moderate level of knowledge, and no cadres with a low level of knowledge; 3). the majority of respondents served as cadres in the prevention of COVID-19, with 60.9 percent (39 respondents) playing an optimal role and 39.1 percent (25 respondents) playing a non-optimal role. 4). There is a correlation between the knowledge of cadres about COVID-19 and the role of preventing COVID-19 which is indicated by the p value (0.001).

\section{Acknowledgements}

Thank you to Allah SWT, both parents and all comrades in arms who have helped from beginning to end.

\section{REFERENCES}

[1] Goruntla, N., Bhupalam, P., Jinka, D. R., Thummala, J., Dasari, L. Y., \& Bonala, K. K., "Knowledge, Perception, and Practices towards COVID-19 Pandemic among General Public of India: A Crosssectional online survey," Current Medicine Research and Practice, 10(4), 153-159. https://doi.org/10.1016/j.cmrp.2020.07.013,2020.

[2] Dinkes Banyumas, " Banyumas Tanggap COVID-19," 0281. covid19.banyumaskab.go.id, 2020.

[3] Kemenkes RI, "Peraturan Menteri Kesehatan Republik Indonesia Nomor 9 Tahun 2020 Tentang Pedoman Pembatasan Sosial Berskala Besar Dalam Rangka Percepatan Penanganan Corona Virus Disease $2019 \quad$ (Covid-19)," $\quad$ Kementerian 28. http://hukor.kemkes.go.id/uploads/produk_hukum/PMK_No_9_Th_2020_ttg_Pedoman_Pembatasan_ Sosial_Berskala_Besar_Dalam_Penanganan_COVID-19.pdf, 2020. 
[4] Kementerian Luar Negeri Republik Indonesia, "Kebijakan Pemerintah Republik Indonesia Terkait Wabah Covid-19," Kemenlu.Go.Id, 1. https://kemlu.go.id/brussels/id/news/6349/kebijakan-pemerintahrepublik-indonesia-terkait-wabah-covid-19, 2020.

[5] Dinkes Jawa Tengah, "Tanggap COVID-19 Provinsi Jawa Tengah: Sebaran Kasus COVID-19 di Jawa Tengah," Corona.Jatengprov.Go.Id, 2021.

[6] Iswinarno, C, "Jakarta Berlakukan PSBB, Pemkab Banyumas Bakal Aktifkan Karantina di Desa," Tersedia di: https://jateng.suara.com, 2020.

[7] Zhong, B. L. et al., "Knowledge, Attitudes, and Practices towards COVID-19 among Chinese Residents During the Rapid Rise Period of the COVID-19 Outbreak: A Quick Online Cross-sectional survey," Int. J. Biol. Sci. 2020, Vol. 16BNPB, BNPB Indonesia COVID-19, bnpb-inacovid19.hub.arcgis.com, 2020.

[8] Notoatmodjo, Soekidjo, "Promosi Kesehatan dan Perilaku Kesehatan," Jakarta: Rineka Cipta (pp. 4562), 2012.

[9] Hamariyana, Syamsianah, A., \& Winaryati, E., "Hubungan pengetahuan dan lama kerja kader dengan ketrampilan kader dalam menilai kurva pertumbuhan balita di posyandu Kelurahan Tegal Sari Kecamatan Candisari Kota Semarang," Jurnal Gizi Universitas Muhammadiyah Semarang, 2(1), 4048, 2013.

[10] Rinayati, Erawati, A. D., \& Wahyuning, S., "Gambaran Tingkat Pengetahuan dan Kinerja Kader Kesehatan," Jurnal Ilmiah Permas: Jurnal Ilmiah STIKES Kendal, 10(3), 359-364, 2020.

[11] Havighurst, R. J., "Developmental tasks and education," New York: David McKay Company. Inc. I 1979, 1972.

[12] Dodo, D., "Faktor-Faktor yang Berhubungan dengan Keaktifan Kader dalam Pelaksanaan Kegiatan Posyandu di Kelurahan," Jurnal Pangan, Gizi Dan Kesehatan Tahun, 1, 2009.

[13] Dinengsih, S., \& Hartati, T., "Hubungan antara Pengetahuan, Pembinaan Kader, Dalamanya menjadi Kader dengan Keaktifan Kader dalam Kegiatan Posyandu di Desa Babelan Kota Wilayah Kerja Puskesmas Babelan di Kabupaten Bekasi," Jurnal Ilmiah Kesehatan, 7(12), 49-55, 2017.

[14] Munfarida, S., \& Adi, A. C., "Faktor yang Berhubungan dengan Tingkat Pengetahuan dan Keterampilan Kader Posyandu," Media Gizi Indonesia, 2(Ix), 1458-1466, 2012.

[15] Nemati, M. et al., "Assessment of Iranian Nurses Knowledge and Anxiety Toward COVID-19 During the Current Outbreak in Iran," Arch Clin Infect Dis. In Press, 2020.

[16] Profita, A. C., "Beberapa Faktor Yang Berhubungan Dengan Keaktifan Kader Posyandu Di Desa Pengadegan Kabupaten Banyumas. Jurnal Administrasi Kesehatan Indonesia," 6(2), 68. https://doi.org/10.20473/jaki.v6i2.2018.68-74, 2018.

[17] Wahyutomo, A. H., "Hubungan karakteristik dan peran kader posyandu dengan pemantauan tumbuh kembang balita di puskesmas Kalitidu-Bojonegoro," UNS (Sebelas Maret University), 2010.

[18] Retnaningtyas, E., Rini, D. P., Praditasari, N. N., \& Cahyani, S. N., "Optimalisasi Pencegahan Konfirmasi Positif Covid 19 Melalui Peran Kader Kesehatan di Era Pandemi Covid 19," Prosiding Seminar Nasional Penelitian Dan Pengabdian 2021, 2, 812-817, 2021.

[19] Pakasi, A., Korah, B., \& Imbar, H., "Hubungan Pengetahuan Dan Sikap Kader Kesehatan Dengan Pelayanan Posyandu," Jurnal Ilmiah Bidan, 4(1), 92118, 2016. 